\title{
STATIC AND DYNAMIC TENSILE CHARACTERISTICS OF S420 AND IF STEEL SHEETS
}

\author{
STATIČNE IN DINAMIČNE NATEZNE LASTNOSTI PLOČEVINE IZ \\ S420 IN IF JEKLA
}

\author{
Mária Mihaliková ${ }^{1}$, Vladimír Girman ${ }^{2}$, Anna Liškováa $^{3}$ \\ ${ }^{1}$ Technical University of Košice, Faculty of Metallurgy, Department of Materials Science, Letná 9, 04200 Košice, Slovakia \\ ${ }^{2}$ P. J. Šafarik University in Košice, Faculty of Science, Department of Condensed Matter Physics, 04200 Košice, Slovakia \\ ${ }^{3}$ Technical University of Košice, Faculty of Metallurgy, Department of Materials Science, Letná 9, 04200 Košice, Slovakia \\ maria.mihalikova@tuke.sk
}

Prejem rokopisa - received: 2015-06-22; sprejem za objavo - accepted for publication: 2015-07-27

doi: $10.17222 /$ mit. 2015.125

Two automotive steels were investigated; the Interstitial Free Steel (IF) HSLA (High Strength Low Alloy) and the S420 micro-alloyed steel. The properties of these materials were determined by static $10^{-3} \mathrm{~s}^{-1}$ and dynamic $10^{3} \mathrm{~s}^{-1}$ rate stress experiments. The plastic properties were determined after static and dynamic tests. The aim of examination of substructures was to determine the distribution of dislocations for various types of stress. The hardness of all the tested materials was higher at a slow rate of deformation. The greater strain hardening of the materials was confirmed by the dislocation distributions.

Keywords: IF steel, micro alloyed steel (S420), dynamic tensile test, hardness (HV1), dislocation structure

Preiskovani sta bili dve jekli iz avtomobilske industrije: jeklo brez intersticij (IF) HSLA (visko trdnostno nizko legirano jeklo) in mikro-legirano jeklo S420. Namen študije je bil določiti spremembe lastnosti teh materialov pri statični hitrosti $10^{-3} \mathrm{~s}^{-1}$ in dinamični hitrosti $10^{3} \mathrm{~s}^{-1}$ obremenjevanja. Plastičnost je bila določena na vzorcih po statičnih in dinamičnih preizkusih. Namen preiskave podstruktur je bil določiti razporeditev dislokacij pri različnih vrstah obremenjevanja. Skladno z izmerjenimi vrednostmi in s podatki iz literature je bila trdota vseh preizkušenih materialov višja pri manjši hitrosti deformacije. Večje napetostno utrjevanje materialov je bilo potrjeno $\mathrm{z}$ razporeditvijo dislokacij.

Ključne besede: IF jeklo, mikro legirano jeklo (S420), statični natezni preskus, dinamični natezni preskus, trdota (HV1), dislokacijska mikrostruktura

\section{INTRODUCTION}

Strain rate, as a modifier of internal structure, is a significant external factor that influences the material behaviour in the forming process. In practice, an understanding of the behaviour of steel under extreme loading conditions is essential for the accurate prediction of material response when a material is subjected to a combination of severe load scenarios such as in collisions. Presently sheets of different qualities are used in the automotive industry. Therefore it is necessary to create research and development for innovation capabilities which could facilitate the rapid development of materials and their cost reduction. The strain rate influences the strength properties through the internal structure and thus affects the material function. ${ }^{1-3}$ Special attention in research is paid to progressive IF Steels and Micro-Alloyed Steels. Interstitial Free Steel (IF) contains only a small amount of carbon $(\mathrm{C}<0.005 \%)$ and has very good deep-ductility, as result of its low yield strength (YS= 100-310 MPa). On the other hand, good deepductility requires higher ultimate tensile strength (UTS $=140-450 \mathrm{MPa}$ ). The material ability to plastically deform without breaking is determined by the ratio $R_{\mathrm{e}} / R_{\mathrm{m}} \cdot{ }^{4-6}$ Micro-Alloyed Steels have a fine-grained ferrite-pearlite microstructure with small quantities (max. $0.15 \%$ ) of precipitates of $\mathrm{Al}, \mathrm{Ti}, \mathrm{Nb}$ and $\mathrm{V}$ bound to $\mathrm{C}$ and $\mathrm{N}^{7}$ The micro-alloying effects are related to the solubility of carbides ( $\mathrm{TiC}, \mathrm{NbC}, \mathrm{NC}$ ), nitrides ( $\mathrm{TiN}$, $\mathrm{AlN})$ and carbonitrides $(\mathrm{Ti}(\mathrm{C}, \mathrm{N})$ ) in austenite and ferrite. ${ }^{7,8}$ An increase of strength can be obtained by grain refinement and precipitation hardening. High strength steels are considered as steels with a nominal yield stress equal to or above $420 \mathrm{MPa}$. The mechanical properties of the Micro-Alloyed Steels are largely a result of a microstructure which depends on the chemical composition and the processing method. ${ }^{9,10}$

\section{EXPERIMENTAL MATERIALS AND METHODS}

Two steel materials, IF Steel and S420 steel with chemical compositions presented in Table 1 were investigated. Tensile testing at the specified strain rates was performed with a Zwick 1387 servo-hydraulic machine with a load capacity of $1000 \mathrm{kN}$ (accuracy $\pm 0.005 \%$ of load capacity). In Figure 1 the size and shape of the test bars is depicted. Static tensile testing was carried out according to the EN ISO 6892-1 standard at three traverse speed loads. ${ }^{11}$ The strain rate was calculated according to Equation (1): ${ }^{12}$ 
Table 1: Chemical composition of IF and S420 steel (in mass fractions, $w / \%$ )

Tabela 1: Kemična sestava IF in S420 jekla (v masnih odstotkih, w/\%)

\begin{tabular}{|c|c|c|c|c|c|c|c|c|c|c|}
\hline Material & $\mathrm{C}$ & $\mathrm{S}$ & $\mathrm{N}$ & $\mathrm{Mn}$ & $\mathrm{P}$ & $\mathrm{Si}$ & $\mathrm{Al}$ & $\mathrm{Nb}$ & $\mathrm{V}$ & $\mathrm{Ti}$ \\
\hline $\mathrm{IF}$ & 0.0013 & 0.0105 & 0.0017 & 0.82 & 0.011 & 0.006 & 0.055 & 0.001 & 0.002 & 0.04 \\
\hline S420 & 0.12 & 0.002 & - & 1.44 & 0.009 & 0.05 & 0.046 & 0.035 & 0.2 & 0.016 \\
\hline
\end{tabular}

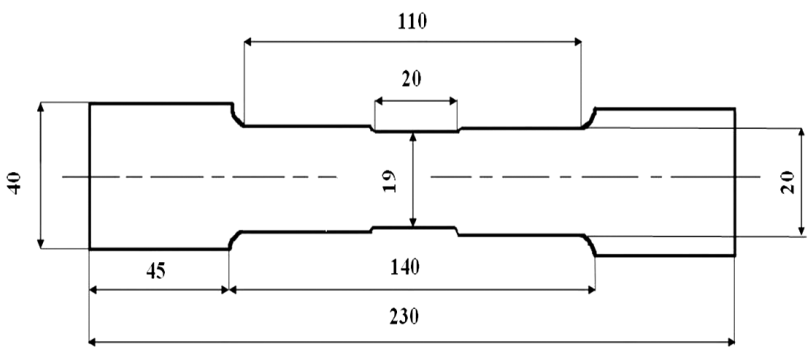

Figure 1: Size of the transverse test bars

Slika 1: Velikost testnih prečnih preizkušancev

$$
\dot{\varepsilon}=\frac{\varepsilon}{t}=\frac{v}{L_{0}}
$$

Where: $\varepsilon$ - relative deformation, $t$ - duration of the deformation, $L_{0}$ - working length of the test bar, $v$ speed of the load

The dynamic tests were performed according to ISO 26203-1 and ISO 26203-2 standards on the rotary hammer $\mathrm{RSO}^{13,14}$ with the data evaluated using the Scope 4 program. Figures $\mathbf{2}$ and $\mathbf{3}$ show the effect of strain rate on yield stress and ultimate tensile strength of IF and S420 steels sheets. In Figure 4 the elongation of both steels (IF and S420) by quasi-static and dynamic conditions is given. The $\mathrm{S} 420$ steel demonstrated an increase of $48 \%$ tensile strength at a strain rate of $100 \mathrm{~s}^{-2}$ showing its better formability by sheet metal forming.

\subsection{Substructure}

The substructure evolution was investigated on samples formed at a static strain rate of $8 \cdot 33 \cdot 10^{-3} \mathrm{~s}^{-1}$ and

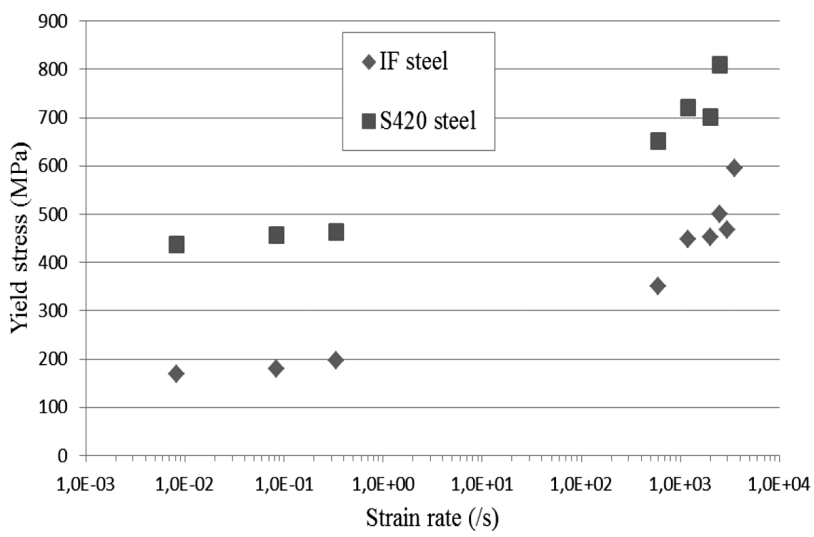

Figure 2: Dependence of yield stress with strain rate of IF and S420 steel sheets

Slika 2: Odvisnost med hitrostjo deformacije jeklenih plošč IF in S420 ter mejo plastičnosti

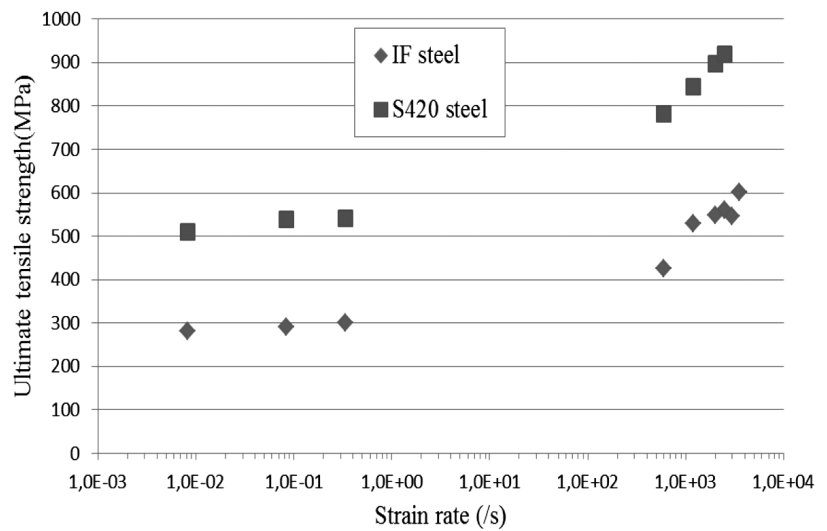

Figure 3: UTS dependence on strain rate of IF and S420 steel sheets Slika 3: Odvisnost hitrosti deformacije jeklenih plošč IF in S420 ter raztržno trdnostjo

dynamic strain rates of $\left(600,2000,3000\right.$ and 4000) $\mathrm{s}^{-1}$. Samples were imaged in a JEOL $2100 \mathrm{~F}$ transmission electron microscope at $300 \mathrm{kV}$ with STEM detector. ${ }^{15}$ Mechanically ground thin plates of $0.1 \mathrm{~mm}$ thickness were then punched out as discs with a diameter of $3 \mathrm{~mm}$. The discs were then electrolytically polished using a double jet device (TenuPol5) in a solution of acetic acid and perchloric acid to obtain specimens for TEM investigation $^{15}$ of dislocations. In Figure 5 planar structures are mainly observed. Such stacking faults and planar dislocation structures (regular dislocation pile-ups, planar tangled bundles) were often observed. After dynamic strain of $\dot{e}=4000 \mathrm{~s}^{-1}$, the dislocations were still mainly present as more evenly distributed planar structures (Figure 6), with stacking faults less often observed. ${ }^{16}$ Figure 7 shows the S420 steel after static strain with numerous dislocation arrangements close to a

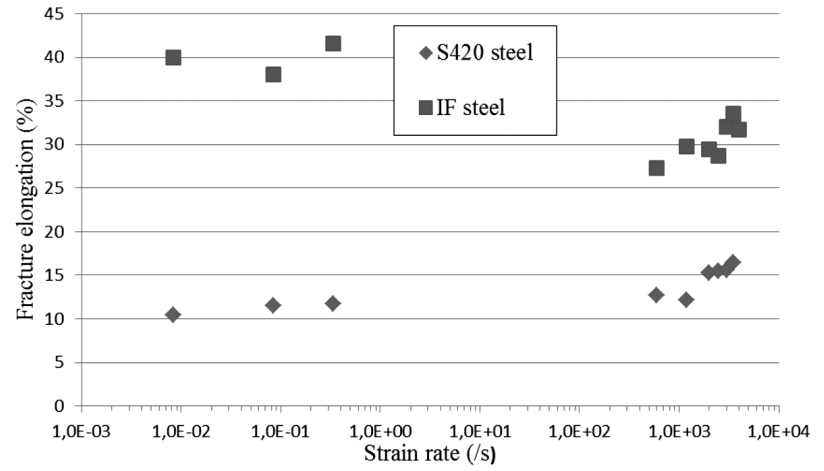

Figure 4: Influence of loading rate on fracture elongation of IF and S420 steel sheets

Slika 4: Vpliv hitrosti deformacije na raztezek pri prelomu IF in S420 jeklenih plošč 


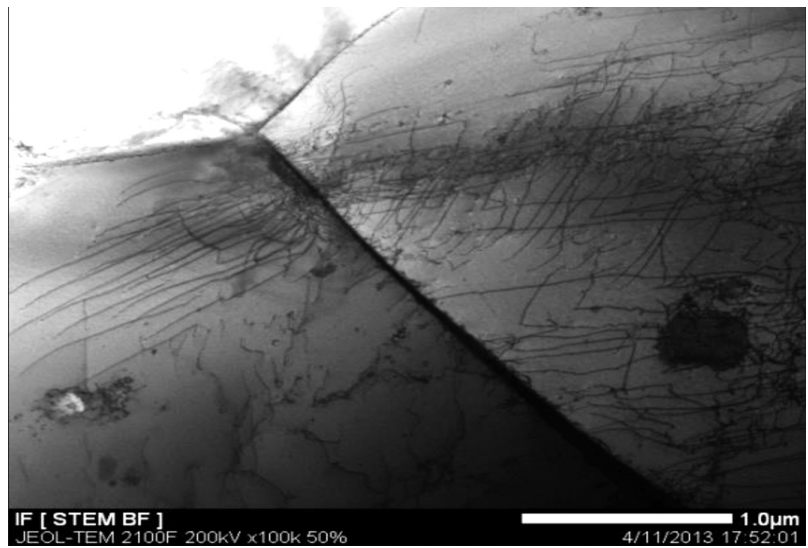

Figure 5: Dislocation structure of IF steel in the static condition $\left(\dot{\varepsilon}=8.33 \cdot 10^{-4} \mathrm{~s}^{-1}\right)$

Slika 5: Struktura dislokacij v statičnem stanju IF jekla $\left(\dot{\varepsilon}=8.33 \cdot 10^{-4} \mathrm{~s}^{-1}\right)$

grain boundary, whereas the dislocations in the middle of the same grain were much fewer. After dynamic strain $\dot{\varepsilon}=3000 \mathrm{~s}^{-1}$, the dislocation density was much higher than that of the static condition, with the dislocations distributed homogeneously (Figure 8).

\section{RESULTS AND DISCUSSION}

The experimental results indicate that the strain rate affects the basic mechanical properties of tested steels. The change of properties is greater by at higher strain rates (Figure 2) and potentially lead to a change in deformation properties (Figure 4). ${ }^{16-19}$ The dependence of the strength properties on the strain rates for the steels tested in the range from $10^{-3}$ to $10^{3} \mathrm{~s}^{-1}$ is described by parametric Equations (2) and (3): ${ }^{20}$

$$
\begin{aligned}
& R_{\mathrm{e} \dot{\varepsilon}}=R_{\mathrm{e}_{\varepsilon_{0}}}+A \cdot \ln \frac{\dot{\varepsilon}}{\dot{\varepsilon}_{0}} \\
& R_{\mathrm{m} \dot{\varepsilon}}=R_{\mathrm{m} \dot{\varepsilon}_{0}}+B \cdot \ln \frac{\dot{\varepsilon}}{\dot{\varepsilon}_{0}}
\end{aligned}
$$

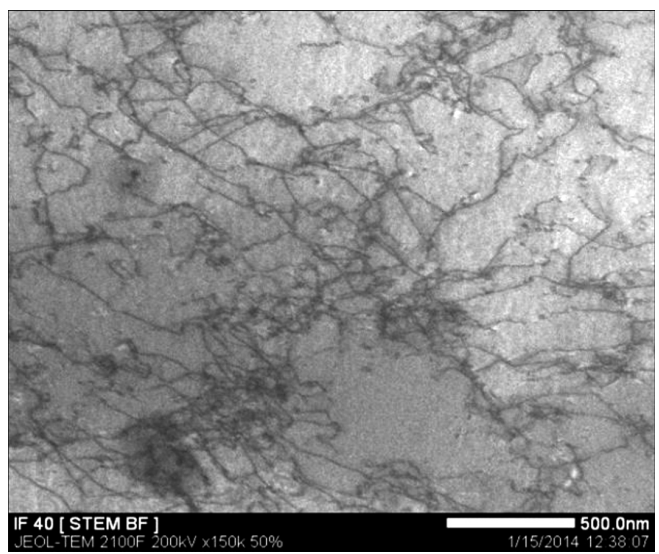

Figure 6: Dislocation structure of IF steel in the dynamic condition $\left(\dot{\varepsilon}=4000 \mathrm{~s}^{-1}\right)$

Slika 6: Struktura dislokacij pri dinamičnem stanju IF jekla $\left(\dot{\varepsilon}=4000 \mathrm{~s}^{-1}\right)$

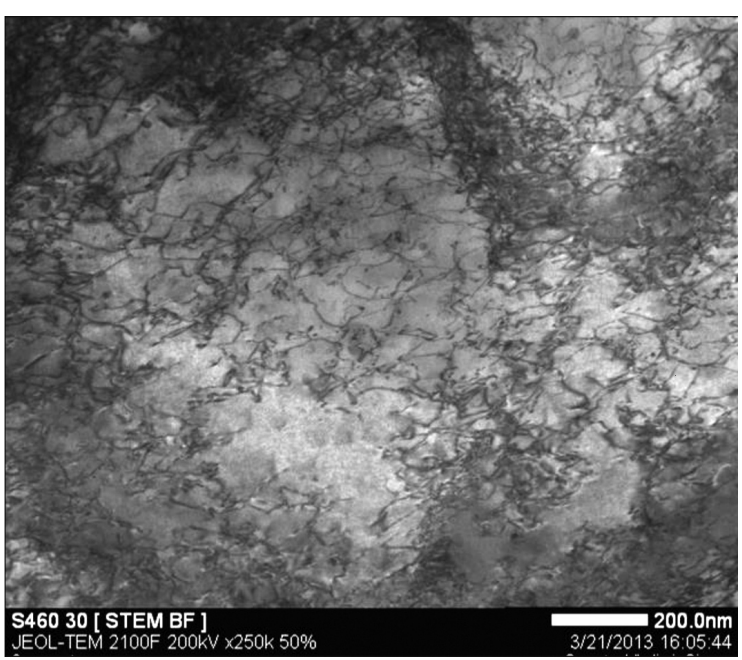

Figure 7: Dislocation structure of S420 steel in the static condition $\left(\dot{\varepsilon}=8.33 \cdot 10^{-4} \mathrm{~s}^{-1}\right)$

Slika 7: Struktura dislokacij pri statičnem stanju jekla S420 $\left(\dot{\varepsilon}=8,33 \cdot 10^{-4} \mathrm{~s}^{-1}\right)$

Where:

$R_{\mathrm{e} \dot{\varepsilon}}$ and $R_{\dot{\mathrm{m}}_{0}}$ are the yield stress and ultimate tensile strength at a given strain rate $\dot{\varepsilon}$.

$R_{\dot{\mathrm{e}}_{0}}$ and $R_{\mathrm{m} \dot{\varepsilon}_{0}}$ are the yield stress and ultimate tensile strength at a static deformation rate $\left(10^{-3} \mathrm{~s}^{-1}\right)$.

The parameters $A$ and $B$ are material constants and express the steel sensitivity to strain rate. With higher $A$ and $B$ parameters, the steel is more sensitive to strain rate, presenting less obstruction to dislocation motion. A and B values of 24.1 and 20.4, respectively, were determined for the IF steel and 16.61 and 24.9, respectively, for the S420 steel. ${ }^{20}$

The greater increase of the strength properties by dynamic stress than by static stress could be explained by increasing lattice resistance to the movement of dislocations. The assumption is if the deformation is dynamic

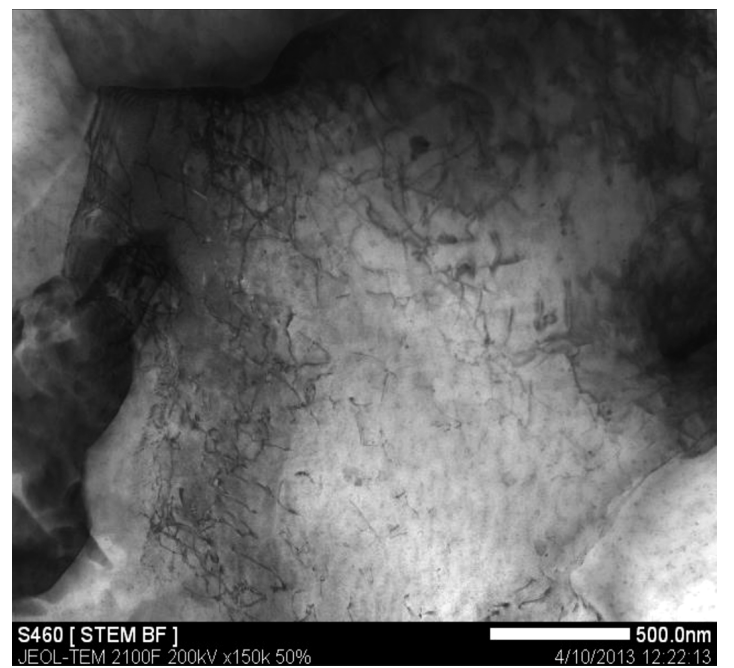

Figure 8: Dislocation structure of S420 steel in the dynamic condition $\left(\dot{\varepsilon}=3000 \mathrm{~s}^{-1}\right)$

Slika 8: Struktura dislokacij pri dinamičnem stanju jekla S420 $\left(\dot{\varepsilon}=3000 \mathrm{~s}^{-1}\right)$ 
there is not sufficient time for it to pass through the best-oriented lattice planes and slip planes yielding higher critical shear stresses and greater stress is required for deformation. ${ }^{21,22}$

\section{CONCLUSION}

The experimental results and calculations support the following conclusions:

- The strength properties of tested steels increase with strain rate.

- The dynamic yield strength is increased substantially with respect to quasi static strain. In an uninterrupted tensile test at a strain rate of $1 \mathrm{~s}^{-1}$ the yield strength (YS $=0.2 \%$ ) is increased by $16 \%$ for IF steel and by $6 \%$ for $\mathrm{S} 420$. With a strain rate $10 \mathrm{~s}^{-1}$, the yield strength was increased by $98 \%$ for IF steel and $49 \%$ for S420. The tensile strength also increased with increased strain rate.

- IF steel with the coarse-grained ferritic structure was more sensitive to strain rate. For yield strength the sensitivity coefficient $A=24.1$.

- S420 steel with the fine-grained ferritic - pearlitic structure and precipitates had a lower sensitivity to the strain rate and the sensitivity coefficient for yield stress is $A=16.6$.

- The dynamic response can be associated with the regrouping of dislocations.

- It is concluded that the IF steel had fewer barriers to the movement of dislocations than the S420 steel. The effect of strain rate reflects the resistance of lattice against the motion of dislocations and was more pronounced in dynamic load conditions.

\section{Acknowledgement}

This study was supported by the Grant Agency of Slovak Republic, grant project VEGA 1/0549/14.

\section{REFERENCES}

${ }^{1}$ S. I. Kim, S. H. Choi, Y. C. Yoo, Influence of boron on mechanical properties and microstructures of hot-rolled interstitial free steel, Materials, Science Forum, 495-497 (2005) 537-542, doi:10.4028/ www.scientific.net/MSF.495-497

${ }^{2}$ S. K. Paul, A. Raj, P. Biswas, G. Manikandan, R. K. Verma, Tensile flow behavior of ultra low carbon, low carbon and micro alloyed steel sheets for auto application under low to intermediate strain rate, Mater. \& Des., 57 (2014) 211-217, doi:10.1016/j.matdes.2013. 12.047

${ }^{3}$ S. Oliver, T. B. Jones, G. Fourlaris, Dual phase versus TRIP strip steels: Microstructural changes as a consequence of quasi-static and dynamic tensile testing, Mater. Character., 58 (2007) 390-400, doi:10.1016/j.matchar.2006.07.004

${ }^{4}$ N. Kamikawa, N. Tsuji, Y. Minamino, Microstructure and texture through thickness of ultralow carbon IF steel sheet severely deformed by accumulative roll-bonding, Scien. and Techn. of adv. Mater., 5 (2004) 163-172, doi:10.1016/j.stam.2003.10.018
${ }^{5}$ M. Jahazi, B. Eghbali, The influence of hot forging conditions on the microstructure and mechanical properties of two microalloyed steels, Journal of Materials Processing Technology, 113, 1-3 (2001) 594-598, doi:10.1016/S0924-0136(01)00599-4

${ }^{6}$ N. D. Beynon, G. Fourlaris, T. B. Jones, Effect of high strain rate deformation on microstructure of strip steels tested under dynamic tensile conditions, Mater. Sci. Techn., 21 (2005) 103-112, doi:10.1007/s 11661-008-9495-4

${ }^{7}$ M. Cabibbo, A. Fabrizi, M. Merlin, G. L. Garagnami, Effect of thermo-mechanical treatments on the microstructure of micro-alloyed low-carbon steels, J. Mater. Sci., 43 (2008) 6857-6865, doi:10.1007/ s10853-008-3000-8

${ }^{8}$ M. Mihaliková, M. Német, V. Girman, DP 600 steel research of dynamic testing, Metalurgija, 54 (2015), 211-213

${ }^{9}$ H. Huh, J. H. Lim, S. H. Park, High speed tensile test of steel sheets for the stress-strain curve at the intermediate strain rate, International Journal of Automotive Technology, 10 (2009) 2, 195-204, doi:10.1007/s12239-009-0023-3

${ }^{10}$ A. Kovalčíková, P. Kurek, P. Balko, et. al., Effect of the counterpart material on wear characteristics of silicon carbide ceramics, J. of Refr. Metal and Hard Mater., 44 (2014) 12-18, doi:10.1016/ j.ijrmhm.2014.01.006

${ }^{11}$ ISO 6892-1. Metallic materials-tensile testing-Part 1: method of test at room temperature; (2009)

${ }^{12}$ M. Mihaliková, M. Német, M. Vojtko, Impact of strain rate on microalloyed steel sheet fracturing, Acta Polytechnica, 54 (2014) 281-284, doi:10.14311/AP.2014.54.0281

${ }^{13}$ M. Mihaliková, M. Ambriško L. Pešek, Videoextensometric measuring of deformation processes in automotive steel sheets at two strain rate levels, Kovov. Mater., 49 (2011) 2, 137-141, doi:10.4149/km2011-2-137

${ }^{14}$ ISO 26203-2 Tensile testing at high strain rates - Part 2: Servohydraulic and other test systems; (2011)

${ }^{15}$ J. Lis, A. K. Lis, C. Kolan, Processing and properties of C-Mn steel with dual-phase microstructure, Journal of Materials Processing Technology, 162-163 (2005), 350-354, doi:10.1016/j.jmatprotec. 2005.02.105

${ }^{16}$ R. R. Balokhonov, V. A. Romanova, S. Schmauder, Finite-element and finite-difference simulations of the mechanical behavior of austenitic steels at different strain rates and temperatures, Mechanics of Materials, 41 (2009) 12, 1277-1287, doi:10.1016/j.mechmat. 2009.08.005

${ }^{17}$ W. Wang, X. Wei, The effect of martensite volume and distribution on shear fracture propagation of 600-1000 MPa dual phase sheet steels in the process of deep drawing, Inter. Jour. of Mechan. Scien.,67 (2013) 100-107, doi:10.1016/j.ijmecsci.2012.12.011

${ }^{18}$ B. Peeters, S. R. Kalidindi, C. Teodosiu, P. V. Houtte, E. Aernoudt, A theoretical investigation of the influence of dislocation sheets on evolution of yield surfaces in single-phase B.C.C. polycrystals, Jour. of Mech. and Phys. of Solids., 50 (2002) 4, 783-807

${ }^{19}$ J. Slota, M. Jurčišin, E. Spišak, T. Sleziak, An investigation of springback in sheet metal forming of high strength steels, Applied Mechanics and Materials, 693, (2014) 370-375, doi:10.4028/ www.scientific.net/AMM.693.370

${ }^{20}$ J. Michel', M. Buršak, The influence of strain rate on the plasticity of steel sheets, Komunikacie, 12 (2010) 4, 27-32

${ }^{21}$ M. Suliga, Analysis of the heating of steel wires during high speed multipass drawing process, Archives of Metallurgy and Materials, 59 (2014) 4, 1475-1480, doi:10.2478/amm-2014-0251

${ }^{22}$ P. Zubko, M. Vojtko, L. Pešek, M. Német, P. Bekeč, Changes in mechanical properties and microstructure after quasi-static and dynamic tensile loading, Materials Science Forum, 782 (2014), 215-218, doi:10.4028/www.scientific.net/MSF.782.215 